\title{
Cash-Flow Model for Efficiency Evaluation in Multinational Trade Enterprises Applying E-Commerce
}

\author{
Arunas Burinskas ${ }^{1}$, Aurelija Burinskiene ${ }^{2}$ \\ ${ }^{1}$ Vilnius University \\ Sauletekio av. 9, LT- 10223 Vilnius, Lithuania \\ E-mail.arunas.burinskas@evaf.vu.lt \\ ${ }^{2}$ Vilnius Gediminas Technical University \\ Sauletekio av. 11, LT- 10223 Vilnius, Lithuania \\ E-mail.aurelija.burinskiene@vgtu.lt \\ cross $^{\text {ref }}$ http://dx.doi.org/10.5755/j01.ee.30.5.22808
}

In this study, the authors have investigated e-commerce in the activity of multinational trade enterprises (MNTEs) and highlighted the main differences between online and offline trade. Many studies are focusing on the application of ecommerce technologies but not on providing efficiency evaluation tool helping to identify how e-commerce technologies change trade business and propose its application in MNTEs. This research aims to provide the cash-flow model for an economic evaluation of investment and operations of e-commerce and traditional trade and the practical application of the model in MNTEs.

To achieve this objective, the authors have proposed a cash-flow model useful for efficiency evaluation and its practical application. According to the case study analysis, trade enterprises which apply e-commerce technologies have approximately 3.7 times fewer employees and 3.1 times fewer investments in long-term tangible assets than other trade enterprises. However, MNTEs performing online business have 5.1 times fewer employees than MNTEs operating in offline. Of course, these numbers depend significantly on business size and the economies of scale.

The study consists of three parts. In the first one, the paper discloses trade business changes determined by the investments into e-commerce. These results are presented on multinational and national business and disclose how actively multinational enterprises (the Mother Companies and their branches) and national ones invest in e-commerce. In the second part, the new cash-flow model is used for efficiency evaluation when trade firms practice e-commerce technologies. In the third part of this paper, the practical application of the model was delivered. Herein several trade MNTEs with and without e-commerce technologies are compared.

Keywords: Cash-Flow Model; E-Commerce; Economic Efficiency; Multinational Trade Enterprises.

\section{Introduction}

Nowadays, modern economies are increasingly focusing on e-commerce, while the application of e-commerce technologies is opening fundamentally new possibilities. It means the emergence of favourable conditions for trade development in national and international markets or the use of new business models.

In the paper, the attention is drawn to the opportunities that bring e-commerce technologies to trade, especially for MNTEs. It is well known that the role of multinationals is vital for the application of innovations (e-commerce technologies as well), especially in the field of uptake of innovations to trade business. On the other hand, the successful and purposeful development of trade must be in line with scientific knowledge and scientifically proved solutions evaluated in terms of efficiency of e-commerce technologies. Usually, e-commerce technologies make trade expenditure lower than traditional trade techniques. Therefore, it is not necessary to invest in store equipment, employ people to work in conventional stores. However, there is a growth of expenditure, essential for the implementation and the maintenance of e-commerce technologies, as well for the installation and operations of the delivery system providing purchased commodities to customers Bergendahl (2005).

The analysis of literature (i.e. review of books published by Oxford University Press, Cambridge University Press, Harvard University Press, Springer, M. E. Sharpe, Routledge, etc.) shows, that only $1 \%$ of them mentions multinational enterprise, while term "e-commerce" is mentioned in $2 \%$ thereof (Table 1). The authors that published books on ecommerce topic gave more attention to efficiency than multinational enterprise. This statistical analysis shows the importance of the bellow presented research which covers ecommerce, multinational enterprise, and efficiency evaluation topics in the area of trade.

Table 1

The Statistical Analysis of Books

\begin{tabular}{|c|c|c|c|}
\hline \multirow{2}{*}{$\begin{array}{c}\text { Number of } \\
\text { publications }\end{array}$} & \multicolumn{3}{|c|}{ In title: Trade } \\
\cline { 2 - 4 } & Efficiency & Multinational enterprise & E-commerce \\
\cline { 2 - 4 } & 806000 & 5180 & 13900 \\
\hline \multirow{2}{*}{$\begin{array}{l}\text { Number of } \\
\text { publications }\end{array}$} & $\begin{array}{c}\text { Multinational } \\
\text { enterprise \& } \\
\text { e-commerce }\end{array}$ & $\begin{array}{c}\text { Multinational enterprise \& } \\
\text { efficiency }\end{array}$ & $\begin{array}{c}\text { E-commerce } \\
\& \text { efficiency }\end{array}$ \\
\cline { 2 - 4 } & 2 & 193 & 831 \\
\hline$\%$ & $0,0002 \%$ & $0,02 \%$ & $0,1 \%$ \\
\hline
\end{tabular}


Researchers need to consider the impact of e-commerce technologies, attempting to present frameworks for multinational enterprises. However, for the efficiency evaluation in retail enterprises, $\mathrm{Lu} \& \mathrm{Hu}$ (2011) propose DEA model; for B2B efficiency setup, Yang, Shi \& Yan (2016) deliver input-oriented fundamental CCR model primarily developed by authors Charnes, Cooper \& Rhodes (1978); for economic evaluation of e-commerce, Saridakis, Lai, Mohammed, \& Hansen (2018) specify marginal effect in SMEs; for consumer efficiency in e-commerce, Kim \& LaRose (2004) present the study and analysis; for innovation performance in multinationals, Figueiredo \& Brito (2011) deliver ANOVA evaluation results; and for the performance of multinationals, Carnevale, Nachum \& Korn (2017) focus on assets value change results.

The multidisciplinary research stands among topics which are selected by international business and ICT scholars, but that is still not combined into the trade studies. Some theoretical and practical studies show that investments into ecommerce technologies determine the necessity to identify and solve the following critical issues linked to trade:

- The existing theoretical knowledge is not adequate to trade changes, which have been taking place in national firms and MNTEs for the last decades;

- The efficiency evaluation of e-commerce application in MNTEs has not been discussed widely.

The object of the research concerns the application of ecommerce technologies for trade activities in MNTEs. And the subject of the study concerns the evaluation of the efficiency of e-commerce technologies in multinational trade enterprises. The main aim of the research is to provide efficiency evaluation tool helping to identify how ecommerce technologies change trade business and propose its application in MNTEs.

The tasks to reach the aim:

- To disclose the business changes determined by the active investments into e-commerce and present the results on multinational and national trade business levels;

- To propose the theoretical model of cash flow and its practical application in MNTEs for efficiency evaluation.

In this paper, first, e-commerce in the activity of trade enterprises: MNTEs and national ones are examined; when model which can be applied to evaluate efficiency is formulated and its empirical assessment is undertaken.

The article is based on comparative, empirical, financial analysis, and discounted cash flow methods.

\section{An Integrated View of E-Commerce Research}

Many authors analyse e-commerce concept (Gregory, Ngo \& Karavdic, 2017; Feng et al., 2017; Yu et al., 2016; Yousefi, 2014; Weisberg, Te'eni \& Arman, 2011, and others). Bergendahl (2005) considers e-commerce as a concept for trade based upon products and services that enterprises market, sell, and get paid for them over the internet. From business perspectives, e-commerce is a tool that addresses the desire of enterprises to cut trade costs. Authors mention that enterprises can start to use e-commerce pursuing different objectives and positive outcomes, and their determination depends on the market situation and the state of ICT awareness within the enterprise. From process perspectives, e-commerce is the application of technology offering automation of workflow and transactions. As an example of it may serve smart cards that facilitate payment in ecommerce and use of other advanced technologies which are relevant to e-commerce (Elbeltagi, 2007). From communication perspectives, the term "e-commerce" means the delivery of information and payments via electronic networks (Boateng et al., 2008). From consumer perspectives, e-commerce associates to the ability to purchase goods worldwide. The term "electronic commerce" refers to the usage of electronic networks in commercial activities which means carrying out financial transactions through the internet, marketing, placement of orders on-line, and transmission of electronic data.

In the landscape of e-commerce, processes and operations are changing significantly. E-commerce differs from the traditional retail in many aspects, among which are the different size of handling unit (pieces picking instead of cases selecting). The order also contains expensive delivery process except for in-store pickups, return policies and service expectations (Piotrowicz \& Cuthbertson, 2014). The physical store could be used as an additional distribution and storage facility where clients pick up online orders, or the orders are shipped straight from the store to clients (Giannopoulos, 2014). Shipping products from store stock is inefficient in terms of delivery costs and time (Napolitano, 2013 ) - due to "last mile" costs and time required for delivery.

The high costs of changing processes and investments into new technology are the factors of concerns related to the implementation of e-commerce activity (Herhausen et al., 2015). Internal conflicts could occur in case different sales channels are incompatible.

Retailers launching e-commerce activity need to shift from single-channel to multi-channel. By doing so, they must evaluate the trade-off between the combination of channels into an integrated system or the establishment of separate systems supporting different channels (Hubner, Holzapfel \& Kuhn, 2015). The separation strategy is selected to respond the specific requirements of the unique channel, whereas an integrated approach is taken to provide the economies of scale and reduce operational costs (Gallino \& Moreno, 2014; Jeanpert \& Pache, 2016). Authors Lee, Chu \& Tseng (2011) reveal that an increase in the application of e-commerce technologies is dependent on labour productivity payoffs perspectives.

Enterprises invest in software, technological equipment and technologies that ensure the safety of payments. Those investments can be evaluated. Aleke Ojiako \& Wainwright (2011) think that funding of e-commerce technologies shall maintain a balance between investments made into an online store and extra its features such as language and convenience of usage. There are many different studies which show that such investments have positive effects (Vehovar \& Lesjak, 2007).

After Bergendahl (2005) had estimated the amount of money devoted to an advertisement, he found that enterprises which are engaged in online trade spend less on advertisement than other enterprises. He noticed that the need to advertise online selling products exists until the critical mass of customers is achieved.

Enterprises, which decided to invest in e-commerce technologies to sell the goods to end-customers, must invest in logistics solutions and to form smaller lots that help with 
providing accurate fulfilments of orders. They focus on the implementation of e-commerce technologies gives the ability to achieve productivity gains in the whole organisation and to generate higher service speed, costs savings, efficiency, and revenues (Wymbs, 2000).

Application of e-commerce: research triangle. The topic of the paper falls into the triangle of critical words: multinational enterprises, e-commerce, efficiency, placed on the vertexes of the triangle, and the single word unifying all others, placed inside of the triangle - trade (Figure 1).

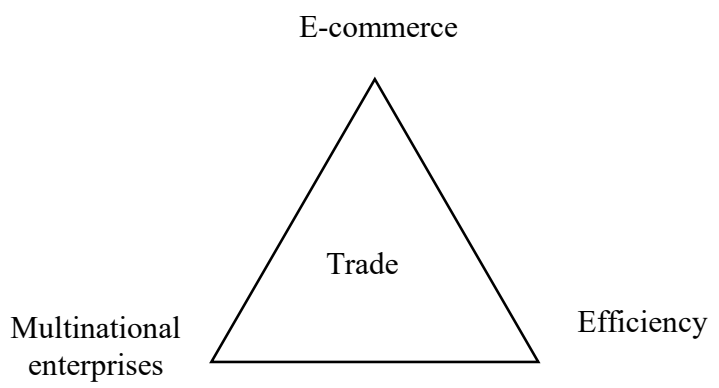

Figure 1. Research Triangle

Bibliometric studies notify that e-commerce was first reported in 1997 when multinational enterprise sold a computer for the first time on the website. Focus has changed during the years. At the early stage, the usability of the web was necessary, while at the second stage customers' transactions were enabled.

The integration of the website with a back-end system and the improvement of inventory management were prioritised at the third stage. This stage also included customised information which was linked with user preferences. Finally, real time interactive capabilities were provided for clients in parallel.

Some words about bibliometric research findings:

1. A literature search since 1997 using subject-related words of research triangle shows over 326 papers (Table 2).

Table 2

Trends in the Study Field

\begin{tabular}{|c|c|c|c|c|}
\cline { 2 - 5 } \multicolumn{1}{c|}{} & \multicolumn{4}{c|}{ Topics } \\
Time & $\begin{array}{c}\text { Multi- } \\
\text { neriod } \\
\text { national } \\
\text { enterprises }\end{array}$ & $\begin{array}{c}\text { Multi- } \\
\text { national } \\
\text { enterprises } \\
\text { \& efficiency }\end{array}$ & $\begin{array}{c}\text { E- } \\
\text { commerce }\end{array}$ & $\begin{array}{c}\text { E- } \\
\text { commerce } \\
\text { \& } \\
\text { efficiency }\end{array}$ \\
\hline $1995-2000$ & 33 & 1 & & 35 \\
\hline $2001-2005$ & 102 & 7 & 2362 & 163 \\
\hline $2006-2010$ & 286 & 4 & 3020 & 198 \\
\hline $2011-2015$ & 386 & 11 & 4162 & 305 \\
\hline $2016-2018$ & 105 & 3 & 1087 & 67 \\
\hline Total & 912 & 26 & 10631 & 768 \\
\hline$\%$ & $100 \%$ & $3 \%$ & $100 \%$ & $7 \%$ \\
\hline
\end{tabular}

2. Authors revised Open source papers and identified such trends in the research field (Table 2). Among revised documents, the number of publications on multinational enterprises and efficiency subject (presented by two lowest vertexes) is significantly small. Much more attention gets ecommerce and efficiency topic (performed by two right-side vertexes). The focus of researchers to e-commerce and efficiency subject is contemporary decreasing compared with the situation in 2001-2015 period.
3. Finally, multinational enterprises topic gets higher attention then multinational enterprise-efficiency or ecommerce-efficiency subjects but lower attention then tradeefficiency theme.

Bellow each research point is presented separately. Let's start from the mid of the triangle.

Application of e-commerce: trade view. In general, multinational enterprises that are more likely seeking to adopt e-commerce technology tend to locate it in the biggest highincome countries. It partly explains the dominance of global e-commerce in the US and EU; of Asian e-commerce - in Japan; of Latin American e-commerce - in Brazil and Mexico. Furthermore, the largest MNTEs can be found in petrochemical and automobile sectors, which partly accounts for the dominance of global e-commerce in automobile and petrochemical enterprises (Gnyawali \& Park, 2011).

In Asia and Latin America, business transactions are mainly conducted on a cash basis and thus not readily convertible to electronic market (Kinuthia \& Akinnusi, 2014). Also, the lack of logistical and technological infrastructures was hampering the growth of e-commerce in regions (Tan, Tyler \& Manica, 2007). For instance, the lack of a reliable domestic transport system to handle express deliveries and packages was found to be the main obstacle for e-commerce growth in China (Kshetri, 2001). The US is the second in the world in terms of technical achievement (UNDP, 2017); the US has the robust logistical and technological infrastructure; also, the penetration of secure payment systems and the usage rate of credit cards is very high. These factors explain the US dominance in ecommerce. Internet-based operations are widely performed by MNTEs, mainly located in the US, a significant portion of which is internal operations between US parents and their foreign affiliates.

Application of e-commerce: multinational enterprise view. A theory of the international firm (multinational enterprise) demonstrates the interaction of three: external environmental and internal knowledge and technology transfer between the Mother company of multinational enterprise and its subsidiaries (Moris, 2017).

It is not easy for multinational enterprise to run at the same time activities which minimize transaction costs, maximize productive efficiency (Oord, 2003), help intake new sales markets, reach net benefit of technology creation and technology augmentation, and obtain various costeffective strategies leading for better competitive position (Romero \& Rodriguez, 2010).

It gives some evidence on how a company could organise its activities, including the creation and improvement of technologies (Figueiredo \& Brito, 2010). The increasing role of innovation and the need for a multinational enterprise to step into, helps the firm to exploit resources and capabilities (Amalia, \& Nugroho, 2011).

Multinationals create advanced technology which has more features than simple ones, that's why multinational enterprise selects the development of new ones rather than optimising the use of present technologies. It is due to the large proportion of skilled labour employed inside each multinational enterprise (Gammelgaard et al., 2011). Among these technologies are information share, marketing, and logistics techniques, etc. 
In general, having higher possibilities to adopt ecommerce technologies and to exploit scale economies, a multinational enterprise can exploit the capacity of any of its plant to exceed internal demand (Lawrence, Klimberg \& Lawrence, 2004). Some multinationals transfer its ecommerce technologies to its subsidiaries. Some authors (e.g. Coppel, 2000 and others) reported that technology transfers of MNTEs were held increasing rapidly.

Appelbaum, Roy \& Gilliland (2011) state that operations of individual plants are based on knowledge of Mother Company, but they are adapted to local content of on-line stores of the foreign countries (Martins \& Antonio, 2010). Forming e-commerce strategies, headquarters of multi-nationals transfer e-commerce technologies to its branches (Buckley, 2014; Buckley, 2016). This development varies from office to branch, depending on the Mother Company's global strategy (Kim, Rhee \& Oh, 2011).

Finally, Jean (2007) delivered the conceptual paper, where the performance of multinational and national enterprises is analysed. Authors mention that MNTEs, being in a dominant position in their industry, could realise economic value such as reduced costs of carrying inventory, obsolescence, and transportation through more accurate and timely information exchange (Carnevale, Nachum \& Korn, 2017).

In general, the attention to the critical role of multinationals in technology diffusion has been increasing (Kotabe \& Kothari, 2016; Rosenblatt, 2011). Mostly large multinationals have been examined (Capo-Vicedo et al., 2011); however, not specifying the ones that are engaged in trade activity. As a result, the role of MNTEs emerges as one of the main topics in studies dedicated to e-commerce.

The application of e-commerce: efficiency view. Under the year 2010 e-commerce topic has reached the most significant attention, also under the year of 2013 joint topic of e-commerce \& efficiency have been highlighted by authors. For example, Xu (2000) delivered the study where the author analyses multinational enterprise and technology diffusion impact on home country productivity growth. The positive effects do not necessarily mean the diffusion of technology by a multinational enterprise. These effects could indicate that multinational enterprise forces competition in the host country and such leads to improved market efficiency and higher productivity (Yang, Shi \& Yan, 2016).

In the flow of material, technology is required to reach process efficiency; on the other hand, the application of technology is expected to be present in the most efficient way (Lu \& Hung, 2011). First, the consumer has to receive expected economic value of purchase, which means that final price (including VAT, taxes, shipment costs, etc.) of item, which is purchased from international on-line store, have to be at least $10 \%$ lower than retail price of the same item presented at purchaser' country. The practical analysis shows that online stores, especially of manufacturers, can offer attractive prices, which means price savings for purchasers. Second, the electronic fulfilment level of the process, must be specially secured, protect privacy, comfortable (less-time consuming) to find specific products on-line, analyse prices, revise all necessary information concerning selling terms, which is essential during purchasing decision process. Third, the physical fulfilment can help to increase consumers' satisfaction in the delivery of goods and services. Lin et al. (2016) delivered a study to investigate the impacts of physical fulfilment service quality on consumer satisfaction using a triadic view of consumer-online-store-3PL.

Using the resource-based-theory as the theoretical background, other authors have found that efficiency could act as a moderator affecting the links between resource capabilities and firm performance (Nath et al., 2010). Infirm efficiency landscape resource-based view explains and gives priority to internal factors rather than external ones, although industrial organisation view revises external factors and their effects. Given studies in the area present interesting insights: resource-based view explains from $\sim 30 \%$ to $\sim 45 \%$ firm efficiency effects, i.e. internal factors; and industry-based picture describes around $20 \%$ of industry effects, i.e. external factors influencing firm performance (Rothaermel, 2012). It indicates that the best approach is to investigate both views and combine them to achieve a firm's competitive advantage.

On the higher-level efficiency could be separated into macro, meso and micro level. Then on the enterprise level authors focus on operational efficiency mainly. Operational effectiveness means that multinational enterprise has carefully to the design of e-commerce strategy to find the proper balance between costs and its ability to offer clients the highest service possible. Hence, the authors see efficiency in relationships between performance and customers' loyalty (Gonzalez \& Chakraborty, 2014).

E-commerce efficiency could be measured separately by incorporating e-commerce specific measures. A significant number of researches was delivered in this area. These criteria range from website design, effectiveness and efficiency of online browsers (information availability and search function) (Tucker, 2008), security issues (Lin et al., 2016). For example, Ramanathan (2010) defines efficiency towards e-commerce websites as their ability to achieve the right presence in terms of operational factors and customer loyalty (Ramanathan, 2010). Singh, Baack \& Bott (2010) discuss web approach and its application points in a multinational enterprise.

E-commerce business choices made by one business company will evoke imitation actions over time, and this will increase the number of competitors. Fast-developing infrastructure and e-commerce technologies allow enterprises to build new processes and structures which, in general, change the way of doing business. It enables companies to reach global consumers with greater efficiency than traditional retail outlets by integrating user-generated content into the store-front presentation (Zhou, Zhang \& Zimmermann, 2013).

The measurement of efficiency has several dimensions: constant return to scale (CRS) and variable returns to scale (VRS), also increasing performance to scale (IRS) and decreasing return to scale (DRS). The VRS efficiency is pure technical efficiency, i.e. a measure of efficiency without scale efficiency. Although the CRS efficiency takes the size of operations: it is technical efficiency which measures inefficiencies due to the input/output configuration and the size of scale. Usually, the score of technical ability for CRS is not equal to the count of efficiency for VRS. Under IRS, the growth of enterprise implies a rise of business efficiency leading firm to dominant (market power) position which is reached by removing other players from the market. The last measurement of effectiveness, DRS is opposite to IRS and shows that business is stagnating. 
Standard transaction cost economics considers transactions from the perspective of static efficiency. Increasingly, attention is required to dynamic efficiency; and the exploitation of deals related to innovations. The theory of enterprises' boundaries is short-run theory, also herein mentioned transaction costs are static and short-run costs. In the long run or during the operating time, all prices become variable costs, so under these conditions, transactional costs are specified as dynamic transaction costs. In general, transactionbased costs' view has been highlighted towards enterprises' setup and promotion of gains which could be achieved by setting up a company as a unique way of coordinating single or multiple economic activities. The presence of transaction costs may involve internal economies of scale and the size aspect of companies, which is a prerequisite for technology implementation (Franco et al., 2011).

There is no single theory of innovation which helps to understand how changes spread in trade business or to explain the internal and external consequences of innovations. Researchers are looking at innovations and consider linking their testing with various theories aiming to explain and understand innovation in enterprise size's context. National enterprises are also innovating, and that could generate diverse options (Tan et al., 2010). Overall, there is necessitating for a reappraisal of static organisational theories, and integration between 'innovation-based' and 'transaction-based' theories of the firm.

\section{The Research Design, the Methodology of the Research and Results}

The research is conducted based on the knowledge accumulated both in the scientific literature (literature-driven) and secondary sources (empirical-driven). The focus of this paper is on a single-stage business model.

The research is given using empirical, financial analysis, and discounted cash flow methods.

\section{Research Statement and Theoretical Framework}

Directions of this research are formulated in the literature:

- E-commerce activities and transition from traditional to on-line trade transactions. Some authors present transitional models starting from simple ones that may be useful for national enterprises up to more complex models applicable by multinationals only (Ahmad \& Sinha, 2016).

- The topic of multinational enterprise is touched in several different economic and business theories.

Following economic literature, some theories may be considered as related to an analysis of multinationals significantly. They are as follows: transaction costs theory, market power theory, evolutionary theory, network theory, resource-based theory, and the paradigm of business process reengineering (shortly presented in Table 3 ).

Table 3

Theoretical Framework: Supportive Theories

\begin{tabular}{|c|c|c|}
\hline Theories & Description & Link with this study \\
\hline \multicolumn{3}{|c|}{ Transaction-based theory (from static to dynamic costs view) } \\
\hline $\begin{array}{l}\text { Standard transaction costs } \\
\text { (TC) theory in economics } \\
\text { (1937) }\end{array}$ & $\begin{array}{l}\text { Transaction costs cover all costs taken-in organizing an economic activity. The } \\
\text { transaction costs theory explains fees of market and internal transactions costs } \\
\text { and the effect of transactions as it is (Strange, 2016). An object of analysis is } \\
\text { transactions. The TC theory names key attributes concerning which deals differ } \\
\text { also, but it considers the only static picture of costs and efficiency. } \\
\text { As internet operations allow for some systematic reduction of TC, many } \\
\text { multinationals simplify their business model and gain efficiency. Some } \\
\text { researchers point not only the shift from physical process to an electronic one } \\
\text { but also sustainability costs thereof (Ong \& Teh, 2016). Many examples of } \\
\text { multinationals cases linked with the implementation of internet-based } \\
\text { operations could be named here. Like, Cisco Systems, which reported savings } \\
\text { in operating costs after implementation of an electronic interface (Wymbs, } \\
\text { 2000). }\end{array}$ & $\begin{array}{l}\text { Transaction costs vary and are linked to } \\
\text { transactions organized in cross-border } \\
\text { scope. Links with the study could be } \\
\text { drawn between different physical and } \\
\text { online transactions, including national } \\
\text { ones and cross-border cases. }\end{array}$ \\
\hline $\begin{array}{l}\text { The evolutionary theory } \\
\text { in economics (dynamic or } \\
\text { evolutionary paradigm) } \\
\text { (1898) }\end{array}$ & $\begin{array}{l}\text { Many authors explain the evolution of MNTEs by its competitive advantage, } \\
\text { which is usually higher than one of the firms competing in the home market } \\
\text { only. Cross-border transfers of knowledge increase MNTEs innovation } \\
\text { capabilities (Kotabe et al., 2016), especially in ICT enabled the business. } \\
\text { The connection between evolutionary theory and transaction costs theory could } \\
\text { be drawn as the path of dependencies. Also, evolutionary theory covers } \\
\text { changes over time and might explain the results of innovation implementation } \\
\text { and their influence on transactional costs. }\end{array}$ & $\begin{array}{l}\text { Taking in mind transfer costs, most of } \\
\text { the studies deliver dynamic } \\
\text { evolutionary frameworks in the context } \\
\text { of trade business expansion. } \\
\text { Evolutionary theory encourages } \\
\text { enterprises to keep changing. And such } \\
\text { an idea is also of this study. }\end{array}$ \\
\hline \multicolumn{3}{|c|}{ The theory of enterprises' boundaries } \\
\hline $\begin{array}{l}\text { The market power theory } \\
\text { in economics }(\sim 1933)\end{array}$ & $\begin{array}{l}\text { Market power is achieved when aggressive investments into innovations bring } \\
\text { the market power to enterprise, while less aggressive rivals have fewer chances } \\
\text { to obtain it. } \\
\text { The market power theory relies on the paradigm of "structure - conduct - } \\
\text { performance" (1933) (Belkhaoui et al., 2014; Beck et al., 2008). MNTEs enjoy } \\
\text { varying degrees of market power, like economies of scale; and also bear } \\
\text { additional costs (including communication costs, risks costs, etc.) related to } \\
\text { indigenous competitors. }\end{array}$ & $\begin{array}{l}\text { Many authors believe that enterprise } \\
\text { becomes multinational one to } \\
\text { maximize returns from obtained } \\
\text { competitive advantages. The effect of } \\
\text { this kind of activity is in the scope of } \\
\text { this study. }\end{array}$ \\
\hline
\end{tabular}




\begin{tabular}{|c|c|c|}
\hline Theories & Description & Link with this study \\
\hline \multicolumn{3}{|c|}{ Transaction-based theory (from static to dynamic costs view) } \\
\hline \multicolumn{3}{|c|}{ Innovation-based theories } \\
\hline $\begin{array}{l}\text { The network theory } \\
\text { (1970) }\end{array}$ & $\begin{array}{l}\text { In networks of MNTEs, branches interact with ones of other, while in general, } \\
\text { it all constitutes some internal and external structure (Cantwell, 2013) which } \\
\text { may bring high cost-efficiency effects from the application of innovations. } \\
\text { The network theory focuses on the relationship between enterprises and costs } \\
\text { sharing mechanism. Furthermore, this theory also engages in the } \\
\text { transformation of resources (Chaston, 2015). }\end{array}$ & $\begin{array}{l}\text { Linking different enterprises and } \\
\text { making up networks; thereby, some } \\
\text { operational efficiency may be } \\
\text { increased. In this theory, guidelines are } \\
\text { drawn to 3PL or 4PL services. Of } \\
\text { course, MNTEs use many service } \\
\text { providers, but in the study, only an } \\
\text { outcome thereof is analysed. }\end{array}$ \\
\hline $\begin{array}{l}\text { Resource-based theory } \\
\text { (1980) }\end{array}$ & $\begin{array}{l}\text { Resource-based theory accepts the diversity of competencies between } \\
\text { enterprises; it focuses on the companies' long-term strategy towards } \\
\text { innovations and the capabilities for up taking them. The main aim is to establish } \\
\text { business models and to develop new ones (Subramanian \& Overby, 2017). } \\
\text { Resource-based theory stays that enterprises are heterogeneous because of } \\
\text { heterogeneous resources they have, meaning that for different strategies, they } \\
\text { could allocate the diverse mix of resources. }\end{array}$ & $\begin{array}{l}\text { The resource-based view is closely } \\
\text { linked with the trade business. Firms' } \\
\text { resources enable it to implement new } \\
\text { strategic directions which improve } \\
\text { business efficiency. }\end{array}$ \\
\hline $\begin{array}{l}\text { The business process } \\
\text { reengineering (BPR) } \\
\text { paradigm (1990) }\end{array}$ & $\begin{array}{l}\text { Reengineering is associated with large-scale innovations and high risk, which } \\
\text { up-taken change brings to a business. Also, the network model is essential in } \\
\text { process redesign success. } \\
\text { Conceptual model of business process reengineering (BPR) has a goal to } \\
\text { understand problems, recognize constraints, and improve the overall } \\
\text { performance of a system. } \\
\text { Buckley (2016) highlights the role of BPR to the competitiveness of MNTEs. } \\
\text { Global operations are cost-oriented with a primary focus to increase economies } \\
\text { of scale maximally, reduce duplication to a minimum, and gain efficiency (Lee, } \\
\text { Chu \& Tseng, 2011). }\end{array}$ & $\begin{array}{l}\text { At the heart of this paradigm is that } \\
\text { each part thereof has its contribution. } \\
\text { There are no overlaps in the system - } \\
\text { each unit is seen as a unique one, which } \\
\text { helps to reach efficiency, and improves } \\
\text { the overall performance of an order. } \\
\text { In this study, contribution to the overall } \\
\text { system of different MNTEs activities is } \\
\text { evaluated as well. }\end{array}$ \\
\hline
\end{tabular}

The object of the theory of enterprise is an entity itself: multinational enterprise or a national enterprise. Therefore, an analysis of multinational enterprise becomes a particular part of a more general study. Anyway, the distinction between multinational enterprise and national enterprise requires multi-level analysis.

This study is a contribution to the evolutionary and multidisciplinary approach. Explaining the competitive advantage of the interdisciplinary approach is essential. Different theories are used for the analysis of MNTEs. Mainly, it is covered in international business literature.

The list of theories mentioned in the paper is not limited. In the last decade, it has received a lot of interest of economists (Dunning, 2000). The multinational enterprise activity might be considered as one of the objects of different economic and international business theories. Therefore, international business scholars are interested in how diverse conditions of the game, impact MNTEs' transaction costs factors at home and outside markets. Those studies highlight geographic distance and unfamiliarity of the country to the firm as the main drivers to establish ecommerce business and measure in terms of economic efficiency. The theoretical framework shows that most of the mentioned theories are complementary to each other and they could be used to explain the gaps between online and off-line linked to multinational trade enterprise activity.

This study is limited to the performance of MNTEs in the domestic market, which is emphasised in internationalisation theory.

To answer these questions, a model is formed and validated. The results of this research show that the suggested model could be a helpful tool in decision making. For this analysis, the method of the two scenarios is chosen. It involves the comparison of traditional and online trade. The scope of the comparison is limited to the home market. The selected market is in the USA as e-commerce is the most dominant there.

\section{Research Directions and Statistical Data Revision}

In this paper, research directions are taken as follows:

1) Both applications of e-commerce technologies in trade performed by MNTEs and expenditure differences are examined.

2) The model, which can be applied to evaluate efficiency, is suggested and, later on, an empirical assessment is undertaken.

Practical examples of e-commerce are analysed. The research itself is based on comparative, empirical, and financial analysis.

For this research, non-random sampling is used. In particular, the data of MNTEs, which is included in Planet Retail (2014) database, is revised.

The sample size is determined by using an online calculation tool. The results showed that the confidence interval is equal to $3.14 \%$.

Also, the research is carried out to emphasise essential expenditure differences. For this part US statistical data is used. This data was collected from both the material provided by the US institutions and information supplied by interviewed enterprises. Assessing data reliability, US Census Bureau (2016) considered that trying to guarantee survey reliability of $95 \%$ when permissible inaccuracy is $4 \%$ (US Census Bureau, 2016).

In the end, the theoretical model involving discounted cash-flow method is suggested.

\section{Chosen Techniques}

Among many methods, it is a cash-flow discountingbased method that is widely used. The technique allows finding out the present value of cash flows, while enterprise is viewed as a cash flow generator. The current value is obtained using a discount rate. Although present value decreases progressively with longer time horizons, the 
competitive advantage of enterprises tends to disappear after some years.

Let's imagine several enterprises with identical income statements and balance sheets but different environment: the first one is with high sales, earnings and potential, and the second one is in fierce competition. The higher value, in this case, will be given to the first one. Of course, various factors affect competitive advantage, but the authors focus on the results of economic activity which generates economic efficiency.

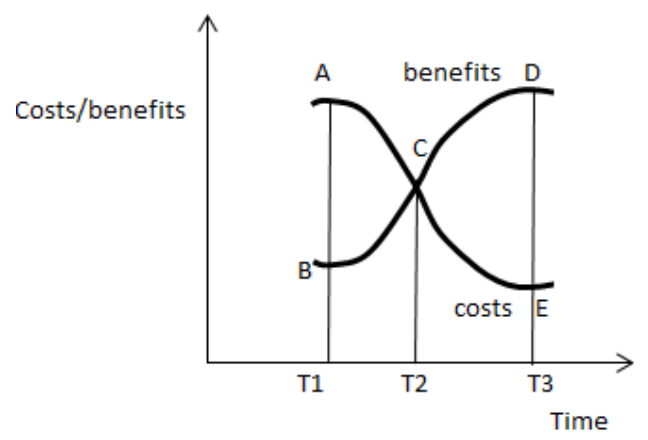

Figure 1. Costs and Benefits in Historical Perspective

To explain this, let's use curves showing the transformation of the enterprise.

Initially, at time T1 (Figure 1), the costs of transactions at point $\mathrm{A}$ are quite high, and the benefits at point $\mathrm{B}$ are low, because of resources consuming process. When the number of transactions expands (reaches critical mass), the costs per transaction are reduced (moved down) (to $\mathrm{C}$ and later to $\mathrm{E}$ ), and benefits move to opposite direction because of the economy of scale (to $\mathrm{C}$ and then to $\mathrm{D}$ ). During the period, the economic benefit increases rapidly. In this particular case, it grew more than twice per period (between $\mathrm{T} 1$ and T3).

\section{Model Design and the Results of the Empirical Assessment}

The performed analysis is based on historical data. Each multinational trade enterprise is at least 14 years old. In order to facilitate comparison, there are at least two enterprises that are located in the same home country. The comparison of MNTEs in the same home market has advantages such as economic conditions, infrastructure development, communication costs, the size of the home market; and social benefits such as labour pay level.

In the research:

(1) Authors use the model of cash flows; it can help to evaluate economic efficiency reached by MNTEs;

(2) Authors separate investments (costs) and results (benefits) for traditional and e-commerce transactions, and highlight the multinational trade enterprise that is achieving higher economic efficiency;

(3) Scenario comparison results show that e-commerce transactions outperform regular ones in terms of total costs.

\section{The Application of E-Commerce Technologies in Trade Performed by MNTEs}

In this section, the application of e-commerce technologies in MNTEs is discussed. To figure out the peculiarities of the use of e-commerce technologies, the following empirical researches are delivered:

- The study focused on business changes determined by the investments into e-commerce. The results thereof are presented on multinational and national business levels;

- The research concentrated on finding out how actively MNTEs (the Mother Companies and their branches) are investing in e-commerce and its application for trade activity.

First, in the research focused on how MNTEs apply ecommerce technologies in trade, 2599, enterprises from 157 foreign countries were examined. The number of enterprises which sell goods using e-commerce technologies in foreign countries was identified using various methods of statistical analysis.

The research was conducted to reveal the usage of ecommerce technologies and to get inputs for one of the criteria, which will be included in the formulated model.

Based on Planet Retail database covering 2910 trade enterprises (in 140 countries of the world), an assessment is made how enterprises apply e-commerce technologies (Planet Retail, 2014). The study revealed that $13 \%$ of trade enterprises (377 enterprises from 2910 enterprises) use ecommerce technologies in addition to traditional trade technologies.

Such results show that the development of the model, which can be applied for the study of the impact of ecommerce technologies, may be a useful tool.

Hereinbelow the comparison of multinational and national enterprises selling commodities by e-commerce technologies is provided. Among the MNTEs $37 \%$ of the enterprises apply e-commerce technologies (111 MNTEs out of 300 MNTEs).

Concerning the application of e-commerce technologies by the MNTEs, the study finds out that $29.9 \%$ of branches of MNTEs (303 branches from 1014 branches which belong to 111 MNTEs) use such technologies.

In comparison, only $17 \%$ of national trade enterprises use e-commerce technologies (74 enterprises of 440 enterprises). The results of the study show that MNTEs use e-commerce technologies more intensively than national ones, including uptake of e-commerce technologies among branches of MNTEs. Also, e-commerce technologies are absorbed in trade more slowly by departments of MNTEs than by Mother Companies.

It was observed that the costs structure of trade enterprises which use e-commerce technologies is different from enterprises which use traditional trade technologies. Enterprises involved in e-commerce invest less in long-term tangible assets and employ fewer employees than enterprises using traditional trade technologies. This research was carried out to emphasise essential differences in expenditure.

It was noted that most trade enterprises using ecommerce technologies (where are 14017 such enterprises in US (US Census Bureau, 2016)) have 3.7 times fewer workers than other trading enterprises (where are 639601 
such enterprises in US (US Census Bureau, 2016). It means that labour productivity is higher in enterprises which apply e-commerce technologies for trade.

Also, enterprises applying e-commerce technologies have 3.1 times lower investments into long-term tangible assets than other trading ones.

It means that such enterprises can achieve substantial cost-efficiencies.

\section{The Model Dedicated to Evaluating the Efficiency of E-Commerce Technologies}

Efficiency is an index measuring the qualitative and quantitative results of economic events and associated with resources allocated to achieve them. Economic efficiency is of two aspects: economic effect and the

combination of used resources (or in other words, a relation between results and expenditure).

The economic efficiency can be evaluated in several ways: as real and expected efficiency. To describe an actual ability, indexes indicating the strength of used technologies in real-time are analysed. Expected efficiency can be identified when it is necessary to evaluate the benefit of ecommerce technologies that are about to apply. To evaluate expected effectiveness, historical data and predictions, which reflect the experience of other enterprises, are used. One of the ways to assess expected efficiency is the evaluation of investments and benefits (increase in incomes or decrease in expenditures) of enterprises that run regular activity or intend to expand the trade.

In literature, MacGregor \& Kartiwi (2005) analyse investments in e-commerce technologies. The authors classify them in either short-term and long-term investments or primary (used to purchase and implement technology) and continual one's (used to develop e-commerce technologies many times).

Various methods of evaluation efficiency include techniques that analyse benefits and costs (Fig. 2). Such techniques focus on assessing costs and results of technological development in the long run. In practice, these techniques help in making investment decisions. As an example, thereof may serve the model suggested by G. Bergendahl (2005) and designed to measure benefits delivered by e-commerce technologies from a time perspective.

In G. Bergendahl's model (2005), the expansion of ecommerce and the growth of sales are the main factors determining the profitability of investments in e-commerce technologies. Therefore, there is a need to assess the development of e-commerce from a time perspective. It is considered that incomes from investments are received immediately after investments are made. Over time, $\left(I_{t}\right)$ revenues increase (1):

$$
I_{t}=I_{0}(1+q)^{t}
$$

where: $I_{t}$ - revenues accumulated over the period $t$; $I_{0}$ - present revenues, $q$ - accumulation standard, $t$ - a period of time.
Also, revenues $\left(I_{t}\right)$ can grow gradually $(q)$, while, on the other hand, it can increase unevenly. Bergendahl (2005) notices that advertisement costs influence the growth of revenues, i.e. the higher advertisement costs, the faster revenues grow.

G. Bergendahl's model (2005) (Figure 2) is helpful in the assessment of both investments in e-commerce technologies and funds which enterprises devote to the advertisement of their e-shops.

Firstly, while enterprises invest in e-commerce technologies, prices of these technologies depend on their flexibility, functionalism, and numbers of potential customers and sales of goods. In this case, investment in technological equipment (server, support infrastructure) and software application (website of an e-shop, extranet, an ecatalogue of goods, and technologies guaranteeing safe payment, etc.) are carried out.

Secondly, enterprises spend specific amounts of money on advertisement. G. Bergendahl (2005) found that companies which engaged in traditional trade before the implementation of e-commerce spent less on an ad. It was found out that conventional trade business needs to invest in advertisement until a critical mass of loyal customers is reached.

Thirdly, selling goods online, enterprises suffer approximately $15 \%$ smaller expenditures than ones practising traditional trade (Bergendahl, 2005).

At the beginning of the e-commerce business, the average costs of sales are more significant. But they decrease if a company expands. It forms an appropriate economy.

Via e-networks well-organised e-commerce business usually gets extra income since its costs tend to decrease. Therefore, to establish benefits of e-commerce, $\mathrm{G}$. Bergendahl (2005) offers to discount (discount is a way of calculating future money based on the present value of total savings. For calculation of net income, G. Bergendahl (2005) subtracts some funds of total revenue which are devoted to the maintenance of e-commerce technologies and trade.

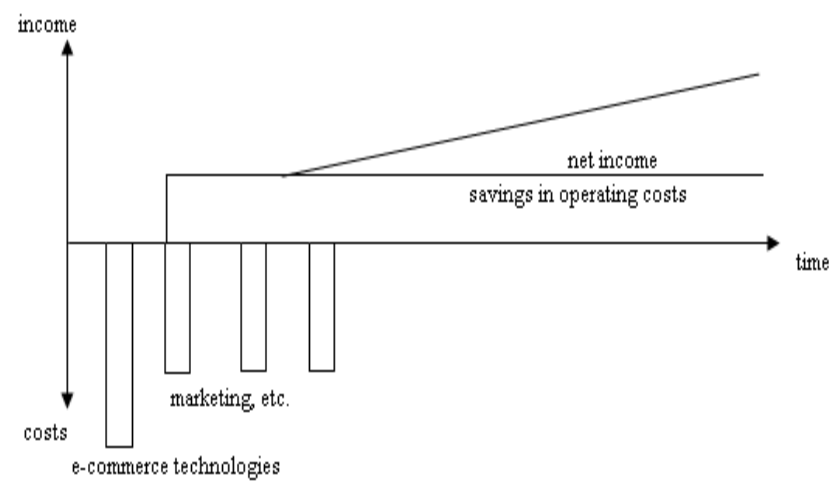

Figure 2. The Model of Cash Flows Generated by Investments Into E-Commerce Technologies (Bergendahl, 2005)

Having summarised the model proposed by G. Bergandahl (2005), it can be concluded that this model is applicable in evaluating efficiency when investments into ecommerce are one-time (single primary investments). 
After the revision of literature dedicated to the efficiency of application of e-commerce technologies, it should be noted that investments into e-commerce technologies can be many-times (multiple continual investments) also.

The cash-flow model shows that savings of operating costs cover follow-up investments. Cash flows are defined as incomes and outcomes of cash and its equivalents incurred during some period after some investments were made (Mackevicius \& Senkus, 2006).

The advantage of the cash-flow method is in calculating the present value of investments, turnover and savings. The method is based on the fact that the risk premium can be included in a discount rate. Martin, Camarero \& Jose (2011) suggest that in e-commerce there are different types of risk in either selling channel (which is specific due to the lack of personal contact with a buyer) or repeated purchases, and other points. Although the method seems simple, still it is challenging to justify the level of the discount rate used in calculations.

The weakness of the cash-flow method is in the process of discounting some factors such as changing inflation and solvency of enterprise, which usually are not taken into account. Even though these factors may influence the current value of cash flows, they may remain not being evaluated.

The cash-flow model is universal. It can be applied when historical (real) and generated (expected) data is analysed. However, cash flows were modelled as positive in all cases. Mora-Monge gives the reason for the assumption, Azadegan \& Gonzalez (2010) - they state that provided evidence concerning the positive impact of e-commerce technologies.

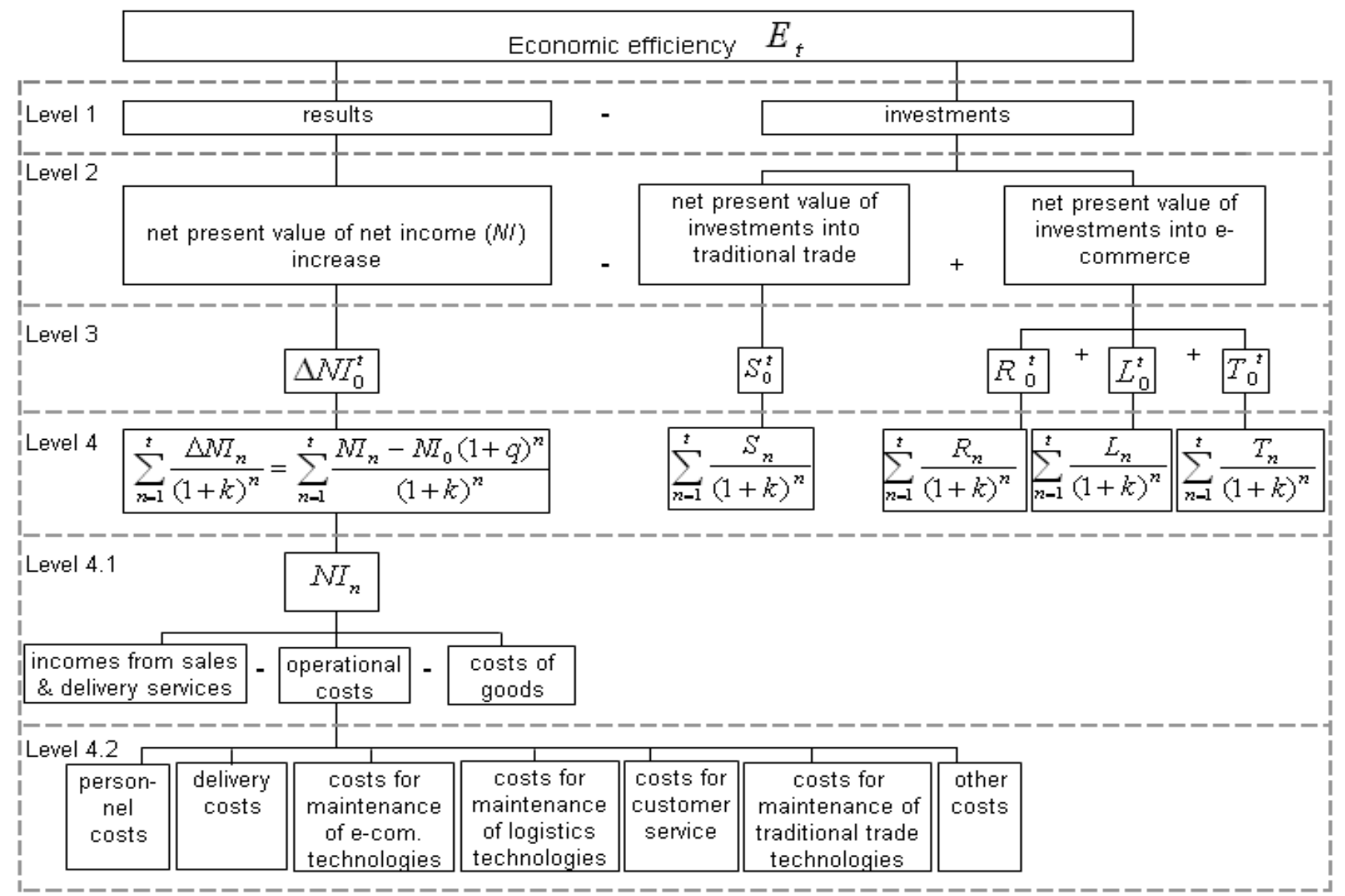

Figure 3. The Model of Cash Flows (Suggested by the Authors)

In Figure 3, there is shown a new cash-flow model where results before $\left(N I_{0}\right)$ and after the usage $\left(N I_{n}\right)$ of ecommerce technologies are measured. Investments of the seller are seen as investments into e-commerce technologies $(T)$, funds devoted to marketing $(R)$ and investments made into logistics technologies $(L)$. As $13 \%$ of traditional trade enterprises apply e-commerce technologies, ventures into traditional trade (S) are included in the presented model. Calculating the present value of investments, discount rate (k) is applied. In the model $\Delta N I_{0}^{t}$ is net current value of net income increase during the period $t, N I_{0}$ - net income before the application of technologies, $N I_{n}-$ net present value of net revenue during $n$ years, $\Delta C_{0}^{t}$ - savings in operating costs received during the period $t, T_{0}^{t}$ - current value of investments, which were made into e-commerce technologies during the period $t, L_{0}^{t}$ - present value of investments, which were made in logistics during the period $t, R_{0}^{t}$ - current value of funds devoted to advertisement during the period $t, S_{0}^{t}$ - present value of investments, 
which were made into traditional trade technologies during the period $t, q$ - accumulation standard (it is assumed that net income $\left(N I_{0}\right)$ can grow gradually $\left.(q)\right), t-$ the whole analysed period from the moment of investments, $E_{t}-$ economic efficiency after the period $t$.

Usually, enterprises that invest in e-commerce suffer even higher costs initially. However, daily costs diminish significantly; therefore, average costs decrease. While prices fall, there is a financial return which means an appropriate economy of activity costs.

In the model, the various levels of economic evaluation (Figure 3) are realised, the deployment of e-commerce technologies reaches the investments and the results. The model can be applied even for enterprises that use both traditional trade and e-commerce technologies in combination.

The assessment of the practical application of the theoretical model is provided in Table 4 and 5. For the empirical evaluation in the cash flow model, two enterprises were chosen. One of them is Amazon.com, which uses ecommerce technologies for selling commodities. And the other one is Wal-Mart Stores, which for selling products use traditional techniques of the trade. The first firm's investments into traditional business are equal to zero $S_{0}^{t}=$ 0 (as Amazon.com doesn't have traditional stores), while Wal-Mart Stores enterprise doesn't invest to e-commerce technologies - they are similar to zero: $R_{0}^{t}+L_{0}^{t}+T_{0}^{t}=0$ (as Wal-Mart Stores doesn't have online store, and it has no incomes from home delivery service and no delivery and maintenance costs of e-commerce and logistics technologies).

\section{The Empirical Assessments of the Cash-Flow Model}

In the empirical assessment of the proposed model were compared two MNTEs: one which uses e-commerce technologies and another one who practice traditional trade.
Limitations of the study. The authors readily acknowledge that many other factors are influencing the performance levels of analysed enterprises. It can be all other technologies but e-commerce ones (or even external factors such as the habits of the population, the usage rate of credit cards, the availability of infrastructure; tax incentives, tariff/non-tariff barriers, and other regulations). A full discussion of what can cause the performance of enterprise overtime extends beyond the boundaries of this paper. So, while the authors acknowledge these other factors, the focus remains on e-commerce alone.

As mentioned, for the comparison two biggest the USA MNTEs are taken: the first one is Amazon.com, and the second one - Wal-Mart Stores. Wal-Mart is the largest retail operation chain in the world and the largest firm in the USA in terms of total annual sales revenue. In the USA Wal-Mart Stores (a subsidiary of Wal-Mart business) enterprise operates more than 4,000 stores in three different formats (3 000 plus Supercentres that sell groceries and general merchandise; 610 Sam's Club warehouse stores, and a growing number of smaller format stores). Wall-Mart Stores takes the first place among traditional retailers: Wall-Mart Stores sales are 5.3 times higher than sales of a retailer which is in the second place (www.stores.org, 2017).

Similarly, Amazon.com takes the first place among ecommerce websites: Amazon.com sales are 1.26 times higher than the sales of eBay, which stays in the second place (www.internetretailer.com, 2016). Also, in 2016, Amazon.com posted a $26 \%$ revenue growth. This shows that Amazon.com built better capabilities than eBay what may lead to its better.

Bellow the overview of these MNTEs is provided. Amazon.com and Wal-Mart Stores employ 24.3 and 2100 thousand employees accordingly. In 2009, the annual income of Amazon.com and Wal-Mart Stores were equal to 24.5 and 405 bln. US dol. Accordingly. In the same year, Amazon.com had the ratio of sales per employee (productivity index) equal to 0.99 , while Wal-Mart Stores enjoyed the rate of 0.19 .

Evaluation of Investments Into E-Commerce: the Case of Amazon.com

\begin{tabular}{|c|c|c|c|c|c|c|c|c|c|c|c|c|c|c|c|c|c|c|c|c|c|}
\hline Model constrains & Markings & 1995 & 1996 & 1997 & 1998 & 1999 & 2000 & 2001 & 2002 & 2003 & 2004 & 2005 & 2006 & 2007 & 2008 & 2009 & 2010 & 2011 & 2012 & 2013 & Sum \\
\hline Incomes from sales (bln. US dol.) & & 0,5 & 16 & 148 & 588 & 1308 & 2182 & 2236 & 2518 & 3259 & 3847 & 4711 & 5869 & 8095 & 10228 & 12828 & 18707 & 26705 & 34813 & 44517 & \\
\hline Funds for logistics fulfillment & $L_{n}$ & 0,1 & 2 & 22 & 88 & 196 & 328 & 268 & 251 & 321 & 334 & 413 & 513 & 705 & 885 & 1074 & $\begin{array}{l}4585 \\
\end{array}$ & 2542 & 3658 & 5133 & \\
\hline $\begin{array}{l}\text { Main operating expences, excluding } \\
\text { fulfillment and funded marketing } \\
\text { activities }\end{array}$ & & 0,0 & 1 & 8 & 61 & 56 & 86 & 64 & 51 & 67 & 69 & 92 & 107 & 128 & 149 & 172 & 257 & 365 & 511 & 675 & \\
\hline Costs of sales (bln. US dol.) & & 0,4 & 12 & 119 & 460 & 1077 & 1665 & 1664 & 1883 & 2392 & 2823 & 3444 & 4523 & 6265 & 7949 & 9933 & 14527 & 20712 & 26196 & 32396 & \\
\hline Funds for marketing & $R_{n}$ & 0,1 & 4 & 18 & 40 & 133 & 142 & 99 & 80 & 83 & 90 & 110 & 144 & 188 & 257 & 356 & 563 & 905 & 1372 & 1873 & \\
\hline $\begin{array}{l}\text { Investments into IT infrastructure, } \\
\text { technology and content }\end{array}$ & $T_{n}$ & 0,2 & 2 & 13 & 45 & 127 & 213 & 173 & 138 & 166 & 157 & 250 & 948 & 649 & 551 & 649 & 948 & 1616 & 2601 & 3925 & \\
\hline Net income (bln. US dol.) & $N I_{n}$ & 0 & 2 & 21 & 67 & 175 & 432 & 508 & 585 & 800 & 955 & 1175 & 1239 & 1701 & 2130 & 2723 & 3923 & 5627 & 8106 & 11446 & \\
\hline E-commerce funds $(n=1, \ldots, t)$ & $T_{n}+R_{n}+L_{n}$ & 0 & 8 & 53 & 173 & 457 & 683 & 539 & 469 & 570 & 581 & 774 & 1606 & 1542 & 1693 & 2079 & 3096 & 5063 & 7631 & 10932 & \\
\hline
\end{tabular}

\begin{tabular}{|c|c|c|c|c|c|c|c|c|c|c|c|c|c|c|c|c|c|c|c|c|c|}
\hline $\begin{array}{l}\text { Net present value of net income } \\
\text { increa } N / I_{\text {bwthed }}\end{array}$ & $\Delta N I_{0}^{t}$ & 0 & 2 & 16,7 & 49,3 & 119 & 272 & 297 & 316 & 400 & 442 & 504 & 492 & 626 & 725 & 858 & 1145 & 1521 & 2029 & 2652 & 12466 \\
\hline Net present value of investments & $T_{0}+R_{0}+L_{0}$ & 0,3 & 7 & 42 & 127 & 311 & 430 & 315 & 253 & 285 & 269 & 332 & 638 & 567 & 576 & 655 & 904 & 1368 & 1910 & 2533 & 11524 \\
\hline $\begin{array}{l}\text { Economic efficiency after } 19 \text { years } \\
\text { (bln. US dol.) }\end{array}$ & $E_{t}$ & & & & & & & & & & & & & & & & & & & & \\
\hline
\end{tabular}


This means that labour productivity was 5.1 times higher in Amazon.com. In general, it shows that MNTEs which apply e-commerce technologies have 5.1 times fewer employees than MNTEs enjoying traditional trade. This difference is high among MNTEs and is much higher than the one between other enterprises (the difference is 1.4 times higher than among MNTEs).

In the cash-flow model, investments into e-commerce technologies and logistics include funds devoted to purchasing software and technological equipment. According to data of Amazon.com performance in 2009, the software was purchased every two years, while technical equipment was purchased every three years. It was applied a discount rate of $8 \%(\mathrm{k}=0.08)$ for calculations of present value.

According to information presented in annual income reports of Amazon.com provided by The Wall Street Journal (2016), for the first five years, its expenditure to advertisement comprises 8-14\% of its income per year on average. The critical mass of customers was achieved after these first five years. Later, Amazon.com increased this kind of expenditure up to $2-3 \%$ of its income per year on average.

Investment in traditional trade technologies involves the funds devoted to the opening of new retail stores, which are present only in Wal-Mart Stores case.

As mentioned, the evaluation of investments into ecommerce (Amazon.com case) and traditional trade (WalMart Stores case) is presented in Table 4 and 5 accordingly. For this comparison of MNTEs historical data of 14 years was used.

Comparing the net incomes of Amazon.com and WalMart Stores, it was found out that the net income of WalMart Stores (Table 5) is 29 times higher than the one of Amazon.com (Table 4). However, investments of Wal-Mart Stores are 31 times more significant. Net income investments ratio for Amazon.com and Wal-Mart Stores is 0.62 and 0.83 accordingly. Overall analysis reveals that that economic efficiency of Wal-Mart Stores is higher 10.7 times only (comparing 14 years data in bln. US dol.) of Amazon.com.

Table 5

Evaluation of Investments Into E-Commerce: the Case of Wal-Mart Stores (The Wall Street Journal, 2016)

\begin{tabular}{|c|c|c|c|c|c|c|c|c|c|c|c|c|c|c|c|c|}
\hline Model constrains & Markings & 1996 & 1997 & 1998 & 1999 & 2000 & 2001 & 2002 & 2003 & 2004 & 2005 & 2006 & 2007 & 2008 & 2009 & Sum \\
\hline $\begin{array}{l}\text { Incomes from sales and delivery services } \\
\text { (bln. US dol.) }\end{array}$ & & & 100 & 112 & 129 & 153 & 178 & 201 & 226 & 253 & 281 & 309 & 345 & 379 & 406 & \\
\hline $\begin{array}{l}\text { Operational costs (which includes personnel } \\
\text { costs, costs for customer service, other } \\
\text { costs) }\end{array}$ & & & 16 & 19 & 21 & 25 & 30 & 34 & 39 & 44 & 50 & 56 & 64 & 70 & 77 & \\
\hline $\begin{array}{l}\text { Investments into traditional trade } \\
\text { technologies }\end{array}$ & & 20 & 3 & 2 & 10 & 5 & 5 & 6 & 8 & 9 & 11 & 11 & 9 & & & \\
\hline Costs of goods sold (bln. US dol.) & & & 79 & 88 & 101 & 120 & 138 & 157 & 176 & 196 & 217 & 238 & 264 & 287 & 306 & \\
\hline Net income (bln. US dol.) & $N I_{n}$ & & 4 & 5 & 6 & 9 & 10 & 10 & 12 & 13 & 14 & 16 & 17 & 22 & 23 & \\
\hline $\begin{array}{l}\text { Investments into traditional trade } \\
(\mathrm{n}=1, \ldots, \mathrm{t})\end{array}$ & $S_{n}$ & 20 & 3 & 2 & 10 & 5 & 5 & 6 & 8 & 9 & 11 & 11 & 9 & & & \\
\hline $\begin{array}{l}\text { Net present value of net income increase } \\
\text { (when } \quad N l_{b}=0\end{array}$ & $\Delta N I_{0}^{t}$ & 0 & 4,0 & 4,0 & 4,3 & 5,4 & 5,4 & 5,2 & 5,4 & 5,5 & 5,6 & 5,5 & 5,4 & 6,4 & 6,0 & 67 \\
\hline Net present value of investments & $S_{0}$ & 18,1 & 2,7 & 1,2 & 6,7 & 3,0 & 2,7 & 3,0 & 3,5 & 3,8 & 4,4 & 3,7 & 2,7 & & & 56 \\
\hline $\begin{array}{l}\text { Economic efficiency after } 14 \text { years (bln. US } \\
\text { dol.) }\end{array}$ & $E_{t}$ & & & & & & & & & & & & & & & 12 \\
\hline
\end{tabular}

Finally, the author calculates "if-if" scenario: if the net income of Amazon.com and Wal-Mart Stores were the same, recalculated economic efficiency would be in favour of Amazon.com. This result might be explained by the fact that enterprises which sell commodities online have smaller expenditure than those which sell products using traditional trade technologies. It has been established that Amazon.com receives a more significant economic benefit than Wal-Mart Stores.

The performed empirical assessment showed that the suggested model could be applied for evaluation of efficiency and comparison of e-commerce and traditional trade enterprises in this respect.

\section{Conclusions}

The multinational enterprise activity might be considered as one of the objects integrating 'innovationbased' and 'transaction-based' theories of the firm, apart from international business theories.
The theoretical framework shows that mentioned theories are complementary to each other. According to transaction costs theory, MNTEs have a strong motivation in implementing e-commerce technologies to lower transaction costs. First, the review of the literature shows that e-commerce operations allow the systematic reduction of transaction costs.

Second, MNTEs, which are known as highperformance organisations, have higher capabilities in adopting e-commerce technologies and exploiting economies of scale, as mentioned in business process engineering paradigm.

On the empiric part of the paper, the focus is delivered on e-commerce activities of the trade MNTEs operating in a single market (the USA market mainly).

To disclose the business changes determined by the ongoing investments into e-commerce and present the results on multinational and national trade business levels, authors deliver the empiric study. 
The results of the first part of empiric study show that $13 \%$ of enterprises operate in both e-commerce and traditional trade. Multinational and national enterprises were also compared to revise effect on trade business. The results show that MNTEs use e-commerce technologies more intensively than domestic enterprises. Branches of MNTEs absorb e-commerce technologies more slowly than its' Mother Company, but, in general, MNTEs do it more actively than national trade enterprises.

The analysis provided in the study reveals that trade enterprises can achieve substantial cost-efficiencies with the help of e-commerce technologies. In general, enterprises involved in e-commerce invest less into intangible assets and employ fewer employees. It was established that enterprises which apply e-commerce technologies have 3.7 times fewer employees and 3.1 times fewer investments in long-term tangible assets than other trade enterprises. The comparison of the two most significant US trade MNTEs, which are dominant in their industry, revealed that MNTEs performing online transactions have 5.1 times fewer employees than multinational one operating in offline markets.

To propose the theoretical model of cash flow and its practical application in MNTEs for efficiency evaluation, the present authors model with its practical application in two MNTEs.

The authors suggest the cash-flow model, which helps to evaluate the efficiency of trade enterprises. The model enables various levels of economic evaluation. It deals with the analysis of investments of e-commerce technologies and the costs of implementation and usage thereof.
The performed empirical assessment shows that the suggested model can be applied for the evaluation of efficiency.

Different MNTEs were compared with the cash-flow model. A multinational enterprise which uses e-commerce technologies trade purposes were compared one that performs traditional trade. The empirical estimation revealed that multinational enterprise receives higher economic benefits despite implemented e-commerce technologies than in case of conventional business (approximately economic benefits are twice more significant). Scenario comparison results show that ecommerce transactions outperform traditional transactions in terms of cost-efficiency.

This research has some limitations. The efficiency evaluation is presented by using a single cash flow method, but it is also possible to use Du-Point method for such analysis.

Further researches could extend this study in the following directions:

- First, in the evaluation of trade enterprises selling goods in multiple markets;

- Second, in the application of the suggested model in other sectors benefiting from e-commerce;

- Third, in the extension of the model. It could be helpful to bring to the comparison multinational enterprise activity in multi-channels (different ways to sell products. covering purchases from the website, phone orders, mail or catalogue orders, interactive TV, and price comparison sites);

- In other directions.

\section{References}

Ahmad, I., \& Sinha, J. (2016). E-Commerce: Adoption Barriers in Small and Medium-Sized Enterprises (SMEs) in India. SMS Journal of Entrepreneurship \& Innovation, (2), 48-53. https://doi.org/10.21844/smsjei.v2i2.11145

Aleke, B., Ojiako, U., \& Wainwright, D. W. (2011). ICT adoption in developing countries: perspectives from small-scale agribusinesses. Journal of Enterprise Information Management, (1), 68-84. https://doi.org/10.1108/174103911 11097438.

Amalia, M., \& Nugroho, Y. (2011). An innovation perspective of knowledge management in a multinational subsidiary. Journal of Knowledge Management, (1), 71-87. https://doi.org/10.1108/13673271111108701.

Amazon.com (2016). Annual information [online]. Available from internet: <http://www.amazon.com/gp/help/customer/ display.html?ie $=U T F 8 \&$ nodeId $=596184>$.

Appelbaum, S. H., Roy, M., \& Gilliland, T. (2011). The globalisation of performance appraisals: theory and applications. Management Decision, (4), 570-585. https://doi.org/10.1108/00251741111126495.

Beck, T., Demirguc-Kunt, A., Laeven, L., \& Levine, R. (2008). Finance, firm size and growth. Journal of Money, Credit and Banking, 40(7), 1379-1405. https://doi.org/10.1111/j.1538-4616.2008.00164.x

Belkhaoui, S., Lakhal, L., Lakhal, F., \& Hellara, S. (2014). Market structure, strategic choices and bank performance: A path model. Managerial Finance, 40(6), 538-564. https://doi.org/10.1108/MF-07-2013-0183

Bergendahl, G. (2005). Models for investment in electronic commerce - financial perspectives with empirical evidence. Omega, (33), 363-376. http://dx.doi. org/10.1016/j.omega.2004.07.021.

Boateng, R., Heeks, R., Molla, A., \& Hinson, R. (2008). E-commerce and socio-economic development: conceptualising the link. Internet Research, (5), 562-594. https://doi.org/10.1108/10662240810912783.

Buckley, P. J. (2014). Forty years of internationalisation theory and the multinational enterprise. Multinational Business Review, 22(3), 205-226. https://doi.org/10.1108/MBR-06-2014-0022

Buckley, P. J. (2016). International Business: Economics and Anthropology, Theory and Method. London: Springer. 
Capo-Vicedo, J., Mula, J. \& Capo, J. (2011). A social network-based organisational model for improving knowledge management in supply chains. Supply Chain Management: An International Journal, (5), 34-43. https://doi.org/10. 1108/13 598541111139099.

Carnevale, M., Nachum, L. \& Korn, H. (2017). Why does multinational enterprise performance vary across countries? International Business Review, (26), 1196-1207. https://doi.org/10.1016/j.ibusrev.2017.05.004

Cantwell, J. A. (2013). Blurred boundaries between firms, and new boundaries within (large multinational) firms: The impact of decentralised networks for innovation. Seoul Journal of Economics, (26), 1-32. https://doi.org/10.1111/more.12026.

Charnes, A., Cooper, W. W., \& Rhodes, E. (1978). A Data Envelopment Analysis Approach to Evaluation of the Program Follow through Experiment in US Public School Education (No. MSRR-432). Pittsburgh: Carnegie-Mellon University.

Chaston, I. (2015). Network Theory Wiley Encyclopedia of Management. Oxford: John Wiley \& Sons. https://doi.org/10. 1002/9781118785317.weom090179

Coppel, J. (2000). E-Commerce: Impacts and Policy Challenges. OECD Economics Department WP, 252, $12-25$.

Dunning, J. H. (2000). The Eclectic Paradigm Market power theory as an Envelope for Economic and Business Theories of multinational enterprise Activity. International Business Review, (9), 163-190. https://doi.org/10.1016/S09695931(99)00035-9

Elbeltagi, I. (2007). E-commerce and globalisation: an exploratory study of Egypt. Cross Cultural Management: An International Journal, (3), 196-201. https://doi.org/10.1108/13527600710775748.

Feng, L., Ma, J., Wang, Y., \& Yang, J. (2017). Supply chain downstream strategic cost evaluation using L-COPRAS method in cross-border E-commerce. International Journal of Computational Intelligence Systems, 10 (1), $815-823$. https://doi.org/10.2991/ijcis.2017.10.1.54

Figueiredo, P. N., \& Brito, K. (2010). The innovation performance of multinational enterprise subsidiaries and local embeddedness: evidence from an emerging economy. Journal of Evolutionary Economics, (21), 141-165. https://doi.org/10.1007/s00191-010-0180-6

Figueiredo, P. N., \& Brito, K. (2011). The innovation performance of MNE subsidiaries and local embeddedness: evidence from an emerging economy. In Catching Up, Spillovers and Innovation Networks in a Schumpeterian Perspective (pp. 171-194). Berlin: Springer. https://doi.org/10.1007/978-3-642-15886-5_8

Franco, M., Haase, H., Magrinho, A., \& Silva, J. R. (2011). Scanning practices and information sources: an empirical study of firm size. Journal of Enterprise Information Management, (3), 268-287. https://doi.org/10.1108/17410391111122853

Gallino, S., \& Moreno, A. (2014). Integration of online and offline channels in retail: The impact of sharing reliable inventory availability information. Management Science, 60(6), 1434-1451. https://doi.org/10.1287/mnsc.2014.1951

Gammelgaard, J., McDonald, F., Tuselmann, H., Dorrenbacher, C., \& Stephan, A. (2011). Effective autonomy, organisational relationships and skilled jobs in subsidiaries. Management Research News, (4), 51-67. https://doi.org/10.1108/ 01409171111117834

Giannopoulos, N. (2014). Converting stores to fulfilment centres. Moving beyond the traditional store. Retail Info Systems News, 3, 23-25.

Gnyawali, D. R., \& Park, B. J. (2011). Co-opetition between giants: Collaboration with competitors for technological innovation. Research Policy, (40), 650-663. https://doi.org/10.1016/j.respol.2011.01.009.29.

Gonzalez, J. A., \& Chakraborty, S. (2014). Expatriate knowledge utilization and multinational enterprise performance: A multilevel framework. Human Resource Management Review, (24), 299-312. https://doi.org/10.1016/j.hrmr.20 14.03.001

Gregory, G. D., Ngo, L. V., \& Karavdic, M. (2017). Developing e-commerce marketing capabilities and efficiencies for enhanced performance in business-to-business export ventures. Industrial Marketing Management, 3, 1-12.

Herhausen, D., Binder, J., Schoegel, M., \& Herrmann, A. (2015). Integrating Bricks with Clicks: Retailer-Level and ChannelLevel Outcomes of Online-Offline Channel Integration. Journal of Retailing, 91(2), 309-325. https://doi.org/10. 1016/j.jretai.2014.12.009

Hübner, A., Holzapfel, A., \& Kuhn, H. (2015). Operations management in multi-channel retailing: an exploratory study. Operations Management Research, 8(3), 84-100. https://doi.org/10.1007/s12063-015-0101-9

Internetretailer.com (2016). Statistics [online]. Available from internet: <http://www.internetretailer.com>.

Jean, R. J. (2007). The ambiguous relationship of ICT and organizational performance: a literature review. Critical perspectives on international business, (4), 306-321. https://doi.org/10.1108/17422040710832568.

Jeanpert, S., \& Pache, G. (2016). Successful multi-channel strategy: mixing marketing and logistical issues. Journal of Business Strategy, 37(2), 12-19. https://doi.org/10.1108/JBS-05-2015-0053 
Arunas Burinskas, Aurelija Burinskiene. Cash-Flow Model For Efficiency Evaluation In Multinational Trade Enterprises...

Kotabe, M., \& Kothari, T. (2016). Emerging market multinational companies' evolutionary paths to building a competitive advantage from emerging markets to developed countries. Journal of World Business, (16), 1-15. https://doi.org/10. 1016/j.jwb.2016.07.010

Kim, J., \& LaRose, R. (2004). Interactive e-commerce: promoting consumer efficiency or impulsivity?. Journal of computermediated communication, 10(1), 70-85. https://doi.org/10.1111/j.1083-6101.2004.tb00234.x

Kim, K. T., Rhee, S. K., \& Oh, J. (2011). The strategic role evolution of foreign automotive parts subsidiaries in China: A case study from the perspective of capabilities evolution. International Journal of Operations \& Production Management, (1), 31-55. https://doi.org/10.1108/01443571111098735

Kinuthia, J. N. K., \& Akinnusi, D. M. (2014). The magnitude of barriers facing e-commerce businesses in Kenya. Journal of Internet and Information Systems, 4(1), 12-27. https://doi.org/10.5897/JIIS2013.0074

Kshetri, N. B. (2001). Determinants of the locus of global e-commerce. Electronic Markets, 11(4), $250-257$. https://doi.org/10.1080/101967801753405535

Lawrence, K. D., Klimberg, R. K., \& Lawrence, S. M. (2004). A multi-criteria DEA framework for evaluating e-commerce efficiency. Applications of Management Science, (42), 49-67. https://doi.org/10.1016/S0276-8976(04)11004-3

Lee, Y. C., Chu, P. Y., \& Tseng, H. L. (2011). Corporate performance of ICT-enabled business process re-engineering. Industrial Management \& Data Systems, (5), 735-754. https://doi.org/10.1108/02635571111137287

Lin, Y., Luo, J., Cai, S., Ma, S., \& Rong, K. (2016). Exploring the service quality in the ecommerce context: a triadic view. Industrial Management \& Data Systems, (116), 388-415. https://doi.org/10.1108/IMDS-04-2015-0116

Lu, W. M., \& Hung, S. W. (2011). Exploring the efficiency and effectiveness in global e-retailing companies. Computers \& Operations Research, 38(9), 1351-1360. https://doi.org/10.1016/j.cor.2010.12.009

MacGregor, R. C., \& Kartiwi, M. (2010). Perception of barriers to e-commerce adoption in SMEs in a developed and developing country: a comparison between Australia and Indonesia. Journal of Electronic Commerce in Organizations, 8(1), 61-82. https://doi.org/10.4018/jeco.2010103004

Mackevicius, J., \& Senkus, K. (2006). The system of formation and evaluation of the information of cash flows. Journal of business economics and management, (4), 171-182. https://doi.org/10.3846/16111699.2006.9636139

Martins, J., \& Antonio, N. (2010). Knowledge transfer to the subsidiaries operating in overseas. Industrial Management \& Data Systems, (4), 516-531. https://doi.org/10.1108/02635571011039007

Martin, S. S., Camarero, C., \& Jose, R. S. (2011). Dual effect of perceived risk on cross-national e-commerce. Internet Research, (1), 46-66. https://doi.org/10.1108/10662241111104875

Mora-Monge, C. A., Azadegan, A., \& Gonzalez, M. E. (2010). Assessing the impact of web-based electronic commerce use on the organizational benefits of a firm. Benchmarking: An International Journal, (6), 773-790. https://doi.org/10.1108/ 14635771011089728

Moris, F. (2017). Intangibles Trade and MNTEs: Supply-Chain Trade in R\&D Services and Innovative Subsidiaries. Journal of Industry, Competition and Trade, (50), 192-204.

Napolitano, M. (2013). Omni-channel distribution: moving at the speed of "now". Logistics Management, 52(6), $42-46$.

Nath, P., Nacchiapan, S., \& Ramanathan, R. (2010). The impact of marketing capability, operations capability and diversification strategy on performance: A resource-based view. Industrial Marketing Management, 39, $307-329$. https://doi.org/10.1016/j.indmarman.2008.09.001

Ong, C. E., \& Teh, D. (2016). Redress procedures expected by consumers during a business-to consumer e-commerce dispute. Electronic Commerce Research and Applications, (17), 150-160. https://doi.org/10.1016/j.elerap.2016.04.006

Oord, J. (2003). Profitable in E-Commerce by Focusing on Operational Efficiency. Media Management, (10), $123-132$. https://doi.org/10.1007/978-3-540-24786-9_14

Planet Retail (2014). Database [online]. Available from internet: $<\mathrm{http}: / / \mathrm{www}$.planetretail.net $>$.

Piotrowicz, W., \& Cuthbertson, R. (2014). Introduction to the Special Issue Information Technology in Retail: Toward Omnichannel Retailing. International Journal of Electronic Commerce, 18(4), 5-6. https://doi.org/10.2753/JEC10864415180400

Ramanathan, R. (2010). The moderating roles of risk and efficiency on the relationship between logistics performance and customer loyalty in E-commerce. Transportation Research Part E: Logistics and Transportation Review, 46(6), 950962. https://doi.org/10.1016/j.tre.2010.02.002

Romero, C. O., \& Rodriguez, D. R. (2010). E-commerce and efficiency at the firm level. International Journal of Production Economics, (126), 299-305. https://doi.org/10.1016/j.ijpe.2010.04.004

Rothaermel, F. T. (2012). Strategic Management: Concepts and Cases. McGraw-Hill/Irwin. 
Rosenblatt, V. (2011). The impact of institutional processes, social networks, and culture on diffusion of global work values in multinational organizations. Cross Cultural Management: An International Journal, (1), 105-121. https://doi.org/10. $1108 / 13527601111104322$

Saridakis, G., Lai, Y., Mohammed, A. M., \& Hansen, J. M. (2018). Industry characteristics, stages of E-commerce communications, and entrepreneurs and SMEs revenue growth. Technological Forecasting and Social Change, (128), 56-66. https://doi.org/10.1016/j.techfore.2017.10.017

Singh, N., Baack, D. W., \& Bott, J. P. (2010). Are multinationals localizing their web sites?: the link between managerial attitudes and multinational enterprise web content. International Journal of Commerce and Management, (3), $258-267$. https://doi.org/10.1108/10569211011076947

Stores.org (2017). Statistics [online]. [accessed 11 February 2017]. Available from Internet: <http://www.stores.org>.

Strange, R. (2016). multinational enterprise theory and the importance of corporate governance. Brighton: Sussex.

Subramanian, H. \& Overby, E. (2017). Electronic Commerce, Spatial Arbitrage, and Market Efficiency. Information Systems Research, 28(1), 97-116. https://doi.org/10.1287/isre.2016.0653

Tan, K. S., Chong, S. C., Lin, B., \& Eze, U. C. (2010). Internet-based ICT adoption among SMEs: Demographic versus benefits, barriers, and adoption intention. Journal of Enterprise Information Management, (1), 27-55. https://doi.org/10. 1108/17410391011008897

Tan, J., Tyler, K., \& Manica, A. (2007). Business-to-business adaption of ecommerce in China. Information \& Management, (3), 332-351. https://doi.org/10.1016/j.im.2007.04.001

The Wall Street Journal (2016). Balances, cash flows and earnings [online]. Available from internet: $<$ http://commerce.wsj. com/amzn\&type.html>.

Tucker, S. P. (2008). E-commerce standard user interface: an e-menu system. Industrial Management \& Data Systems, (8), 1009-1028. https://doi.org/10.1108/02635570810904587

US Census Bureau (2016). Database [online]. Available from internet: <http://factfinder.census.gov/servlet/IBQTable? bm=y\&-ds_name $=\mathrm{EC} 0700 \mathrm{~A} 1>$.

UNDP (2017). Human Development Report [online]. Available from internet: http://www.undp.org/hdr/completenew.pdf

Vehovar, V., \& Lesjak, D. (2007). Characteristics and impacts of ICT investments: perceptions among managers. Industrial Management \& Data Systems, (4), 537-550. https://doi.org/10.1108/02635570710740689

Weisberg, J., Te'eni, D., \& Arman, L. (2011). Past purchase and intention to purchase in e-commerce: The mediation of social presence and trust. Internet Research, (1), 82-96. https://doi.org/10.1108/10662241111104893

Wymbs, C. (2000). How e-commerce is transforming and internationalizing service industries. Journal of services marketing, (6), 463-478. https://doi.org/10.1108/08876040010347598

$\mathrm{Xu}$, B. (2000). Multinational enterprises, technology diffusion, and host country productivity growth. Journal of development economics, 62(2), 477-493. https://doi.org/10.1016/S0304-3878(00)00093-6

Yang, Z. Shi, Y., \& Yan, H. (2016). Scale, congestion, efficiency and effectiveness in e-commerce firms. Electronic Commerce Research and Applications, (12), 171-182. https://doi.org/10.1016/j.elerap.2016.07.003

Yousefi, A. (2014). E-commerce: efficiency and welfare. Journal of International Business and Economics, (14), $150-162$. https://doi.org/10.18374/JIBE-14-1.14

Yu, Y., Wang, X., Zhong, R. Y., \& Huang, G. Q. (2016). E-commerce logistics in supply chain management: Practice perspective. Procedia Cirp, 52, 179-185. https://doi.org/10.1016/j.procir.2016.08.002

Zhou, L., Zhang, P., \& Zimmermann, H. D. (2013). Social commerce research: An integrated view. Electronic commerce research and applications, 12(2), 61-68. https://doi.org/10.1016/j.elerap.2013.02.003

The article has been reviewed. Received in January 2015; accepted in December 2019. 